\title{
Complementary and Alternative Medicine as a Functional Tendency. Formation of Preferences, Agency, and Diffusion Among Citizenships
}

\author{
Antonia Ramirez, Perez, PhD \\ Pablo de Olavide University \\ Seville, Spain
}

doi: 10.19044/esj.2016.v12n26p52 URL:http://dx.doi.org/10.19044/esj.2016.v12n26p52

\begin{abstract}
The work is centered in the social analysis of the formation of preferences and in the description of the social action related with the complementary and alternative medicine (CAM). The theoretical framework that will help to show this generation of preferences is the fashion theory and the social tendencies theory. And to illustrate this reality it has been get an empirical body of information from the Seville city, Spain, as case study. The mixed methodology used allows to show the narrative of the process as well as the 'pictures' in particular moments. To the first objective, it has been carried out ethnographic fieldwork from a decade. To the second objective, it has been elaborated a database with the complementary and alternative medicine activities offered in Seville. Both methodologies help to show a map of this disruptive innovation and the shape adopted.

The results show that CAM tendency emerges because it is useful to the society. Beyond the seasonal fashions, the irruption of this disruptive fashion indicates a process of social change with a new understanding of the health. In the CAM the preferences are generated for instrumental and axiological reasons, though it seems that axiological rationality would be a powerful explanation when we observe its emergence. And finally the results show a group of innovative people as the agents of the change. Moreover, they would seem to be the group that accelerate the process until the tipping point, from which the trend expands thanks to the processes of mimesis or contagion.
\end{abstract}

Keywords: Sociology of Tendencies, Complementary and Alternative Medicine, Formation of Preferences, Social Change

\section{Introduction}

The complementary and alternative medicine (CAM) term refers to the use and benefit of non-allopathic medicines, which are more and more present 
in daily life of Western societies. These disciplines or medicines are mainly characterized for the relation of the person with the environment from a holistic view; from this holistic logic, illness and health are integrated concepts, but with a minor role. Whereas, wellbeing, good life, self-care, are set as guides or models, new linguistics codes which synthesize symbolic expressions of a new health and wellbeing trend.

This work shows the emergency in the society of this new medicine, in particular, the work is centered in the social analysis of the formation of preferences and in the description of the social action (Boudon, 1981; Elster, 2003) related with CAM. The theoretical framework that will help to show this generation of preferences is the fashion theory and the social trends theory. And to illustrate this social reality it has been get an empirical body of information form the Seville city, Spain, as case study.

In this work the Sproles (1974) proposal about the fashion processes is adapted to the most innovative theories of socials trends and fashion. The features presented here are the object, the emergence, the shape, the diffusion and the consolidation ${ }^{l}$, and the writing is organized in several parts, according to these aspects of the fashion theory. The first part deals with the object of the fashion, the complementary and alternative medicine, and their arising in Seville metropolitan area. Following to Robertson (1967), a discontinuous innovation in the fashion's world is showed, specifically the emergence of an offer in health services which 15 years ago would have been unthinkable.

The second part argue that CAM is a functional trend, in opposition to the non-functional ones, because it generates changes in the society, that is, their analysis allows to observe the social change. A third part shows, on one hand, the agents of the change, and on the other hand, the mechanism of the fashion diffusion. In that way, we will get to know the agents who are making possible the fashion emergence, the innovators: the erudite, the connectors and the traders. Meanwhile the innovators group start up the tendency, the diffusion mechanisms try to explain the expansion of the fashion as a social virus, and the reason behind this contagion.

\section{Methodology}

To show the CAM map the research has obtained the information by using two different approaches. On one hand, during ten years an ethnographic workfield has been carried out in CAM scenes. The participant observation has been the main ethnographic tool, sometimes living during short periods in places related to some complementary or alternative activity, like meditation centers; in most cases the participant observation was carried out by practicing and learning: yoga, New German medicine, energy healing, and

\footnotetext{
${ }^{1}$ The feature dimensions of the change over time that describes the change to other fashion, it is not
} included because has not happened in CAM yet. 
Phsy-K, mainly; or by applying an activity: osteopathy, naturopathy, traditional Chinese medicine, biomagnetism, sintergetic, bioenergetic psychology, analytical psychology, among others. The methodology applied in the ethnographic fieldwork could be consulted in the Appendix 1, which shows the reliability and validity criteria that have been used. On the other hand, it has gathered information for two years with the intention to elaborate a database with the CAM activities offer of Seville Metropolitan Area (MA) ${ }^{2}$. The Appendix 2 shows the technical information about the database elaborated during 2013-2014. Thus, for this period the database incorporates the offer of activities carried out in the MA.

Therefore, mixed methodology shows the object and the process of the fashion, the two basic elements for the study of fashion, and with both quantitative and qualitative sociological methodology, in the way to show the social reality with as many instruments as possible (Bericat, 1998; Callejo, 1998).

\section{Results and Discussion}

\section{Emergency and disruptive innovation of complementary and alternative medicine}

According to the fashion theory, the object of the fashion is the essential element for the description of any process. In this study, the object is constituted by the CAM, that are the set of practices offered as a product in the market. As any fashion, the CAM medicine emerges from the convergence of collective likings of any phenomenon present in the society. In the CAM case, people start to get involved with professionals who diminish their illness, and who practice non-conventional medicine usually away of the public health system. The decrease or reduction of the pain happens, in some cases, thanks to the acupuncture system applied in some parts of the body; in other cases, the illness starts to disappear without surgical procedures, thanks to the handling in specific parts of the body, done by an osteopathy professional; some people increase their level of awareness and mental control, and improve their bio-psycho-social wellbeing thanks to meditation or yoga practice. These are some examples of CAM activities, and that characterized its emergence. In fact, they show the peculiarity of this medicine in relation to other fashions: being able to be characterized as a disruptive innovation (Robertson, 1967), understood as the introduction of a new market product that requires new behavior patterns for their development.

The discontinuous innovation appears in the city of Seville 15 years ago, in a constant but timid way, in the middle-end of the 90's, beginning of

${ }^{2}$ Health and Wellbeing Project (PSyBP), from Pablo de Olavide University (Cod. APP2D09503). I would like to thanks to the Professor Rosalía Martínez for advices and support, and to the students that helped with the database elaboration, specifically to Raúl Navarro. 
the XXI Century, though some complementary and alternative medicine as the homeopathy, the naturopathy and the acupuncture root their origins at the beginning of the 80's, when arise the first associations of this kind of medicine (Ramírez, 2015). Whether the 80's are the beginning of CAM, in the 90's the first yoga schools, centers for family constellations teaching, sacro-craneal and osteopathy examination rooms, and the meditation shangas were born. The joining to this disruptive fashion implies a high participation in the cognitive process and in the taking decision process, in opposition to the behavior close to the continuous innovations, which only imply incremental changes in an object that is socially accepted - as the new colors in the smartphone technology.

As Rogers and Shoemakers (1971) point out, the product or object has to be perceived with a relative advantage, if it wants to have room and space facing the social predominant practice. A number of CAM qualities talk about this relative advantage ${ }^{3}$. The qualities would be:

(1) The CAM is above all a preventive medicine. Although in the market is addressed to the illness solutions -dysfunctions of the circulatory system, nervous system, digestive system, locomotor system, etc.- the truth is that CAM's use and application prevent all of these kind of illnesses; (2) Many of CAM practices are related with an "active patient behavior" in the sense that the application of the medicine is an exclusively patient action, and the professional is above all in the role of teaching the skills. Once learned, this medicine is a self-administration medicine, -like meditation, yoga, pilates, taichi, family constellations, Psych-K, Bach Flowers, dance therapy, or reiki; (3) Most of the CAM is a harmless medicine as the administration does not have counter-indications, and in case of misapplication it would not have adverse effects $^{4}$; (4) In fact the CAM is characterized for medicine-free goal, and when

${ }^{3}$ The qualities showed below, have been gotten from the ethnographic fieldwork, that is to say, they have been obtained from (1) the discourses of the participants in the fieldwork, (2) from the sceneries where the participation has been done, (3) the documents managed in the learning and practice rooms. Therefore, these qualities are going to be expressed in etic language from the emic analysis language. These qualities are also reinforced by the results and conclusions of studies that have been carried out from several decades ago. The research in CAM is rich, above all in relation to the qualities showed here. The research's centers and researcher's projects are large, in accordance to the extend variety of CAM activities. The reader could check, among others, the 2013 Traditional and Complementary Medicine publication by the World Health Organization (OMS 2013), The National Center for Complementary and Alternative Medicine (NCCIH), The Journal of Complementary and Alternative Medicine (JCAM), European Journal of Integrative Medicine (EUJIM), Research in Complementary Medicine (RCM), Chinese Journal of Integrative Medicine (CHJIM), the abstracts presents in the several Regional and International Congresses on Integrative Medicine, or The CAMbrella project.

${ }^{4}$ According to Nature's Therapies Dossier by the Spanish Health Department developed in 2011, although these techniques tend to be considered more harmless than those of the conventional 
medication is administrated, they are free of adverse effects as fitoteraphy, oligotherapy, flowers or others medicines are used (Goci et al, 2013) ${ }^{5}$; (5) The point (3) and (4) would reduce health risks as well as increase the people's quality of life; (6) Regarding the conventional medicine, the CAM is showing impressive results in the stress disorder, perhaps the XXI Century illness (Dambrun et al., 2012; Ekman et al., 2005; Goyal et al., 2014; Perez and Holmes, 2000; Radhika and Kumari, 2014; Szekeres and Wertheim, 2015) .

Therefore, the complementary and alternative medicine arises as a disruptive medicine form from the present medicine so far in the Western society, the allopathic medicine. In this moment, and in this room of emergence, according to Foucault (1979), the two actors become present into the scene, and occupy their own place in the stage, the allopathic and the alternative.

\section{The shape of the fashion: functionality and ideology The functionality of the fashion}

The qualities and features of CAM above referred are related with the functionality of this tendency. The fashions can be functional or nonfunctional and both arise from the collective convergence likings; However, the first ones are associated to the context evolution, that is, the social framework of the period allows the understanding of the evolution of the fashion $^{6}$. Moreover, the functional fashion exists due to the utility or purpose, unlike the non-functional fashions (Erner, 2013). And this utility seems to be

medicine, in some cases the users have been hurt for practitioners without qualification. In other cases, it has also happened, and associated with the item (4), that the problems detected are related with not to inform to the doctor about the herbal self-medication, or the users have used falsified products by ignorance, or non-adequate therapies, and even there have been cases of non-intentional overdose. The professionals contacted have pointed out repeatedly the unsuitable utilization of different alternative medicines simultaneously, because one of them could invalidate the effects of the other, and viceversa. For example, the professionals note the inappropriate use of phytotherapy and homeopathy simultaneously, or reiki and meditation, or Psych-K and Gestalt.

5 The debate about non-allopathic medication products developed for specialized pharmaceutical, is currently present. This analysis is not the object of this work, although we are not ignorant to this discussion.

${ }^{6}$ The non functional tendencies are developed by the likings, the shapes and the colors evolution, and neither theory until now can explain why the election of this color or shape in a specific social context: the hipster fashion and the t-shirt with butterflies showed in the store windows of London, Berlin or Seville, very fashioned style in the moment to write these lines, obey to a non functional fashion, and as well as it is now a fashion, it might have been not, or could have been in other sociohistoric contexts. In the functional fashion case Chronos, the Universal Time's God, helps to understand the emergence, in the second case, non functional, Chornos plays with the stylists and coolhunters. 
generating a shift in the practices and the beliefs. Almost all the professionals contacted in the fieldwork pointed out these changes in the people that are using the CAM: the trend is generating changes among the citizenship in relation with health, changes that are affecting the relation of the individuals with their body, family and environment.

But, which aspects of the health are attended on this complementary and alternative medicine offer? To show this fashion and get to know a little more about their functionality, a classification of CAM has been done. The classification will help to recognize which dimensions of health and wellbeing are attended with this new medicine. It has been elaborated from the theoretical definitions of the different types of medicine, and it is corroborated with professional reports published by public administrations and professional experts. It is necessary to highlight the great diversity of CAM techniques; 94 activities have been found in Seville MA, and they are not the only ones that exist (Ramírez, 2015a). The work document elaborated in 2011 by the Spanish Health Department includes more CAM activities, and are not the same activities found in this study. As an example of this explosion of activities, in the ethnographic fieldwork the expression 'the street market therapies' is used ${ }^{7}$.

The classification that follows includes the total of activities in one or another classificatory criteria according to the underlying dimension identified in each activity. Based on that information the classification is elaborated with 6 categories, that are in accordance to the exclusion and exhaustiveness criteria of the social classifications (Bartolini, 1986) ${ }^{8}$. However, the peculiarity and particularity of these activities makes it difficult to follow the criteria in a perfect way. For example, integral systems, such as traditional Chinese medicine (TCHM), carry out activities that could be included in other categories, and these activities can be developed in an autonomous way from the integral system from where they came from. In that way, some handling

7 The ethnographic fieldwork has allowed to observe the complicate world related to the CAM terminology. Activities, therapies, medicines and disciplines are all terms that try to express similar realities with some linguistic and symbolic differences. For instance, the term therapy, that implies the treatment of an illness, it shouldn't be used anymore in the opinion of some professionals, although others professionals defend their use. The different understanding of health is the cause of these two approaches. Other example, some professionals would desire the CAM would be included as a part of the naturopathy concept, but others don't understand systems as the Traditional Chinese medicine, a complementary and alternative medicine, into this term of naturopathy. And another more, for some professionals the term CAM would be appropriated to use for yoga or chi-kung disciplines, whereas others professionals don't consider these as a medicine but as an art of living.

8 The next classification is adapted from 1) The USA National Center for Complementary and Alternative Medicine (NCCAM) classification, 2) the classification included in the Nature's Therapies Dossier by the Spanish Health Department developed in 2011, 3) The Administrative Decision of August 12, 2013, by the Spanish Labor and Social Insurance Department, that publishes the First National Labor Agreement about Naturopathy and Professionals on Naturopathy. 
techniques such as auriculotherapy or ear acupuncture, from the TCHM, are also carried out by professionals who are not TCHM doctors. It seems therefore, inappropriate to exclude these activities from the classification though they are implicitly included in some medicine activities. As another example, the consciousness techniques could modify the energy field of the person. The meditation, for example, among other results, implies the harmonization of the energy field, but it does not act directly in this field, as other healing techniques do. In this case, the classificatory criterion does not exclude the meditation from both categories, however, it places the activity wherever is more strongly expressed ${ }^{9}$.

The illustration 1 presents the distribution of the offer of complementary and alternative medicine activities according to the classification. From a total of 444 units of analysis among centers, associations and consultation rooms, a total of 1338 items of activities have been gathered. That is, a center or a consulting room can carry out one, two or several activities of those 94 . In that way it could be said that there are up to 3 activities diversification per professional or businessman.

Illustration 1. Complementary and Alternative Medicine Classification. Seville 2013-14.
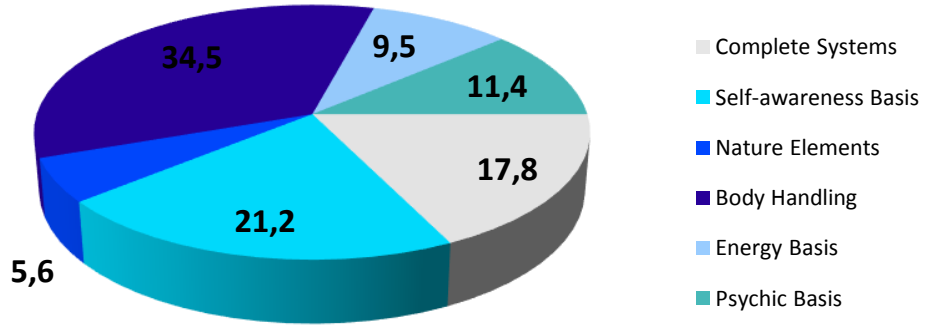

Source: Own elaboration.

For the Sevillian metropolis case it can be observed a larger presence of some categories above others. The handling practices are the top practices in the activities offered, with a $34 \%$ from the total. That is, it seems that Seville CAM users like to be "touched", because $1 / 3$ of the activities are related with it. It can be through massage, as the Balinese, or warm stones; it can be with

\footnotetext{
${ }^{9}$ A deep analysis about CAM activities, inclusion criteria in the classification, and description of the classification is showed by Ramírez (2015a).
} 
techniques related with the muscle-skeleton structures: osteopathy, metamorphic technique; it could be done by the handling of specific parts of the body that have their impact, as a reflex, in several parts of the human body: reflexology, reflex-kinesiology.

The next group of offered activities are those related with the consciousness techniques, with over $21 \%$ of the supply aggregate in this category, $1 / 5$ of the whole offer. Holotropic breathwork or dance therapy would be characterized by the movement of the body, opposing to meta medicine or meditation, where the body is not necessarily in movement. As a whole, a group of activities oriented to increase our capability of mental control, our levels of awareness.

In the third place, the integral and complete systems representing the $17,8 \%$ of the total supply. This category includes activities as naturopathy and homeopathic medicine, both with a large tradition in the Western culture; the ayurvedic medicine or the shamanic medicine are also in this group, strongly rooted in their origin countries and with increasing relevance in the Western healthy systems (OMS, 2013). Therefore, this third group, unlike the handling body group or the awareness group, is centered in the offer of a complete medical system or theoretical body.

The above group is followed by the psyche and mental patterns techniques, representing $11,5 \%$ from the total of the supply. In addition to the hypnosis, it includes the "new psychologies" - Psych-K, bioenergetics, etc.-; the therapies consisting in the change of mental patterns from the creativity would be found here too - music therapy, laughter therapy...-. It includes also a group of activities based on our mental strengthening and our capability to modify it - neurolinguistic programming (NLP), coaching, among others. As a whole, nearly $10 \%$ of the offer is related to the work with the psychological dimension.

Close to the $10 \%$ would be also the offer of energy techniques, some of them would require the professional expertise for their application sintergetic, reconective healing-, and others with a relative level of autonomous work in their use, once the training has been done -reiki and chakras work. The offer, thus, is connected with the harmonization of the body energetic field, non-visible, and the location of areas with lack of energy, or disproportionate energetic densities, and the conduction to a harmonized plane.

The biological practices and with nature elements would be the least offered with $5,6 \%$ of the total offer. The majority of the treatments are applied without any oral administration, such as the aquatic balance therapy, hydrotherapy..., although there are also some which are orally administrated. Among them, the phytotherapy and the macrobiotic. Many of these therapies are traditionally spread in spas or healthy resorts with a strong tradition in our 
country, where the diet and hydrotherapy and mudtherapy sessions are the essence for a range of illnesses, from rheumatism to asthma.

Therefore, we could state that CAM is a functional fashion to the system, and the utility or functionality lays above all in the social element contribution, specifically in the social change that come from the understanding of the illness and health through the new practices that are included in the CAM notion. This paper establishes a map of this utility from the perspective of the offer of activities, that is, from a group of people, professionals and entrepreneurs trying to set a tendency facing the other medicine branch. In addition, the utility or opportunity of the fashion could be deeply understood in attention to the underlying dimension that surrounds the CAM practices: handling manipulation, consciousness techniques, integral systems, mental pattern techniques, energy techniques, and nature elements.

\section{The ideology of CAM}

The understanding of the fashion functionality allows us to proceed one step forward on its meaning, on the social use of CAM. In the previous part it has been pointed out that the functionality also could change the set of beliefs present in the society. Actually, a special feature of the functional trends is its possibility to be expressed as ideological tendencies, in the sense that they can be understood as innovations or re-emergences of sets of ideas political, social, economic, religious... principles- that guide the social, political, and cultural organizations and systems. From the ethnographic work carried out seems to be suitable to point out that the new medical fashion brings a value changing proposals, with the intention to affect the norms that rule the societies. The CAM is a way to understand the individual in relation to the environment, as the main or basic element, beyond the simple physical o material individual approach. It is a return to the awareness of the human being as a whole ${ }^{10}$.

Besides, the complementary and alternative medicine holds a wider ideology, because it is not only about health but also about wellbeing (Baarts and Pedersen, 2009; Sointu, 2006). In fact, a deeper analysis shows the relation among wellbeing and stress. The ethnographic fieldwork has developed long and varied conversations, as well as active participation, where one of the principal aspects addressed for wellbeing is the deceleration of life's rhythm.

${ }^{10}$ The academic researches carried out on the quantum physic, and the inclusion of the oriental practices, especially the Buddhism and their several branches, and the traditional Chinese medicine (Aczel, 2008; Capra, 1984; Rubia, 2002) are examples of researches showing new Western societies approaches related to health, and parallel to the mainstream: the human being is not only a physical body and cannot be studied by parts, but by its totality. 
Therefore, if social thinkers as Barthes (2005) pointed out that fashions are related to the "essentialism", to the spirit of the age, it can be suggested that CAM brings a fundamental rupture to the current age spirit: the accelerated and stressing view as one of the main features of the post-modernity. Facing the stress of our society, facing the Momo book "gray men" going to our home with their briefcase to steal our time, facing the time we need to stop running every moment in our lives, the complementary and alternative medicine bring us a rupture with stress, one deceleration of our activity and daily routines.

But wellbeing is also related with consumption, and the several ways to take awareness about what and how is consumed. The reference group put into practice activities based in other consumption differently from the mainstream. For example, from the ethnographic work the emphasis would be to eliminate 'fast food' consumption from the family diet, especially among the youngest. Whereas hygienist, vegan or vegetarian diets are being incorporated. Another example would be the search of a new relationship with nature. The social entertainment is no longer located in the big shopping malls but in the nature environment, not for being consumed but for being enjoyed and heard. Even more, the wellbeing incorporates the non-consumption possibility. For example, from the ethnographic work is observed a decrease in the consumption at pubs and places with "adulterate" food, the search for alternative solutions regarding to pharmaceutical products, allopathic as well as non-allopathic, or an increased awareness that the consumption does not satisfy our desires.

This originality of the fashion as a social change expression, became gradually a norm in use (Ostrom, 1999), almost in the most stable societies dimension, the cultural changes. The social room where the new values and beliefs are internalized is growing and spreading in a progressive and stepped form; it does not happen overnight, as we are showed above. This social change, on the other hand, we have pointed out that happens from a holistic view where the parts cannot be separated nor analyzed in an independent way from the totality. In the same way, CAM deals not only with the physical dimension of the individual but also with other aspects of the self. Perhaps one form to observe it in the reality is sharpening a little more the statistical analysis and looking for the underlying dimensions that are present in the categories above showed. Looking for the existence of a probable underlying dimension a factorial analysis has been carried out. The results of this analysis can be consulted in the appendix 3. The factorial, explaining around 55\% of variance, shows clearly two dimensions, one of each consolidates three of the six categories to the prior classification. The graphic expression of the factorial information is showed on illustration 2. The first factorial factor shows an important association among the "integral systems", "biologic practices", and "handling techniques" categories. The second factor presents association from 
the categories "consciousness-based techniques", "energy-based techniques", and "psyche-based techniques". The activities from the first factor joint the physical expressions of the individuals, the more material or "lattice" aspects of the person: people go to a holistic doctor when a physical pain is felt, which treatment might include some nature substances administration as well as some handling in the affected part of the body. The activities from the second factorial, however, are joined around the energetic and less visible aspect of the person, this individual dimension that remains in the ethereal or subtle part: an activity of this dimension is carried out when the person feels disharmony or imbalance in some aspect of their life, or when this aspect of the human being wishes to be strengthened.

Illustration 2. Material and subtle dimensions of the CAM activities offer.

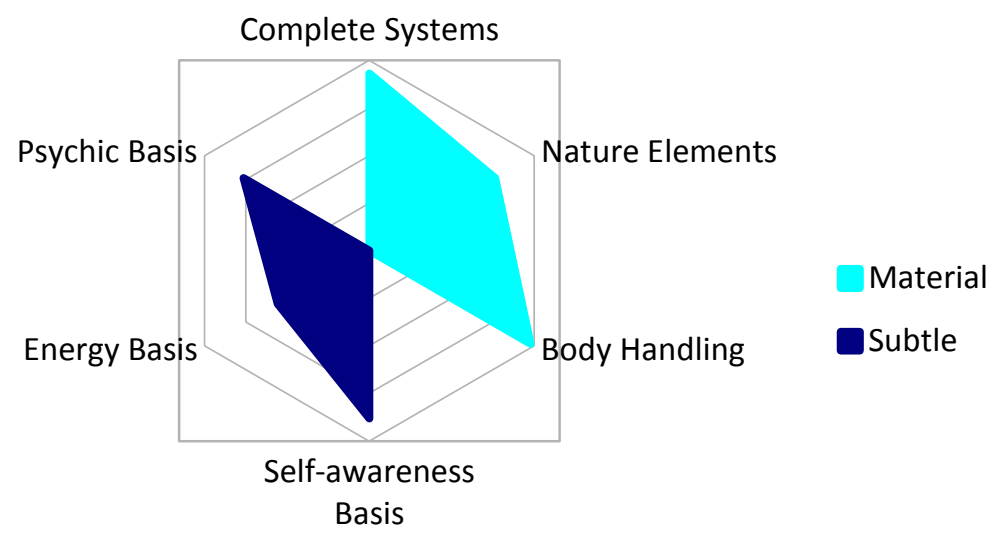

Source: Own elaboration.

Thus, it could relate to a material and an ethereal factor as underlying dimensions of the offer of complementary and alternative activities. And this is perhaps one of the most important elements of this type of medicine, that is empirically displayed on the illustration 2. Not only it is talking about the holistic dimension of illness and health when it is referring to CAM, it is also talking about overcome the conventional health definition and go beyond including more comprehensive concepts of wellbeing and self-care. If this is one of the most important questions that is defended by the protectors of this medicine, the expression of this subtle dimension is the other aspect demanding recognition among these professionals. The auric or energetic aspect is needed to understand the aspects related to people's health and wellbeing. And this is integrated in an ideology, a life ideology. 


\section{The dissemination: agents and mechanisms \\ The agents of the change}

A particular feature of all fashions, whatever they may be, is that they cannot be allocated to any specific social group, they do not have subject. In the democratic modernity, their spread will depend on the changing likings; and not having to be joined to any natural group attributes, as gender, nor achieved, such as the social class. Any person can participate in the fashion independently to their religion, residence place, political affiliation, or sexual preferences. So it is usual to talk about fashions as a "non-subject" phenomena. However, to characterize the fashions as a non-subject phenomena does not mean that there are no people putting them into action, and individuals that follow them. The fashion sociology pays special attention, on one hand, to the innovators, the group that starts up the fashion, facing the adopters, on the other hand. Next, both CAM groups are presented. In fact, if the CAM arises is actually thanks to the elite or vanguard people developing these types of practices. These elite or leaders, in Sproles words, do not necessarily belong to any social class, and not even to an upper class, in opposition to other social theoretical thinkers (Bourdieu, 1979; Sproles, 1974). This condition might be present, but it is not necessary for the starting up of the fashion. Maybe who has best conceptualized this question so far would be Gladwell (2000), which differentiates among mavens, connectors, and salespersons, putting into context the social class and leadership conceptualizations.

Maven is a term from the Hebrew and its meaning is related to "understanding". Being a maven could be compared with being a yogi in the Hindu culture. The mavens as well as the yogis have a large knowledge, are able to express it in order to make it understandable, and know the way and the moment to do it. As transmitters of knowledge, they are a simple tool: their aim is the transmission of wisdom without feeding the ego. The IndoEuropean vocabulary could translate it as erudite or wise person. The connectors, as its name suggests, are people in the fashion start up linking the knowledge, on one hand, and the demand, on the other hand. Finally, the salespersons have the ability to spread the fashion. These three agents enable the change. All three could be found in one person, a businessman who apart from having CAM knowledge, act simultaneously as a connector and as a salesperson. It could be represented as a businessman owner of an integral medicine center, acting as a connector and also as a salesperson. It also could be only a maven person, and spread their knowledge in a CAM center, so carrying out only one of the three aspects.

The illustration 3 shows the main characteristics of the Sevillian change agents in the three abilities that they could or could not develop simultaneously. The first feature that stands out in the chart is that there are 
women $(47 \%)$ as well as men $(53 \%)$ (Gender). With a percentage difference of three points, it seems that the startup of the innovation is carried out by males and females. Instead, it seems that there are three aspects that characterize the groups that initiate the CAM practices. On one hand, almost all of them are professionals of private societies (88\%) (Entity). This was expected in a city where the private initiative is the mainstream in complementary and alternative medicine. This fact suggests that besides mavens, they are also connectors, but above all, they are salespersons, getting involved in the capital investment to start up a business.

Illustration 3. Who are the mavens, connectors and salespersons? Descriptives.

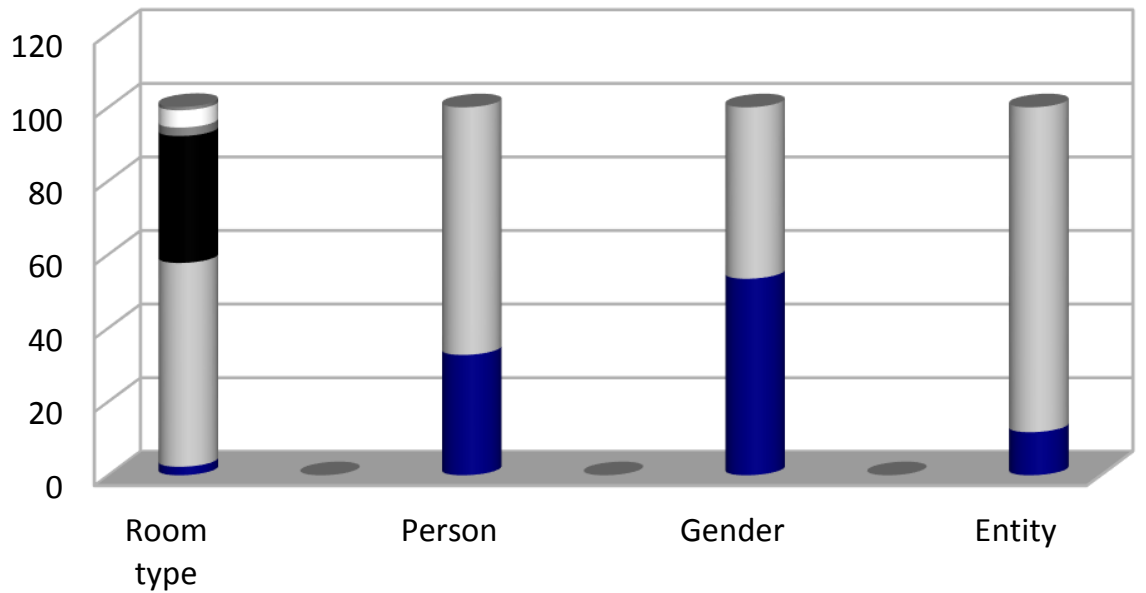

Source: Own elaboration.

Finally, the fourth feature, the regulation, where the legal entity is $2 / 3$ more important than the natural person (67\% facing 33\%) (Person). This should indicate that starting up the activity involves at least two people, a maven and an innovator, business partners, and even when the risks and obstacles are higher than the ones that will face a natural person regulation, the funding benefits are more important than for the natural person; besides of becoming potentially initiators of employment because their participation in several categories of work agreements. But above all, the legal entity seems to imply stability and continuity to the society, suggesting a significant challenge for this medicine as an economic factor in the Andalusian metropolis.

The entrepreneurs of the change are, thus, men and women bringing together CAM initiatives into the city market with stability and continuity perspectives. Startup 'un negocio', Andalusian term that refers to the opening of a commercial business, is also an option for this medicine. 


\section{The mechanisms of diffusion and of explanation}

As presented above, the dissemination is another feature in the fashion process, where the protagonists are the adopters or the followers. The CAM has been capable to assemble the subjective aspect with the objective aspect, because in addition to aggregate individual interests, has also been spread in the society. According to the survey carried out in 2008, the $90 \%$ of Spanish population knew about some CAM activity (OTN, 2008). That is, the spread among the citizenship was already spectacular in 2008. The contagion, the mimesis, has been the most accepted dissemination mechanism among the sociologists, facing other reasons related with technological innovation or functional utility perceived (Sproles, 1974). Contagion but not on whatever thing, the object and its practice must have enough hook for the dissemination success. For theorists, the democratic state logic, giving freedom to individuals to decide about their destiny is in the root of the explanations. The key principle "a man, a vote" and the emergence of the Estate as the legal building that rules the citizenship equality, gives the individual enough autonomy and social adulthood to be responsible to take their own decisions. Some of the theorists agree that the reduction of the panic in the choice would answer the transmission of the fashion (Simmel, 1957); others theorists as Keynes agree the reduction of uncertainty to the social action election (Davidson, 1991). In both cases, besides, the underlying rationality is the instrumental one, in Weber words, the intelligible mechanism is explained thanks to the instrumental rationality: lessen the panic, lessen the uncertainty.

In the CAM case, the diffusion mechanism is still the mimesis: the society adopts the new trend through the contagion. However, as well as it is true that the citizenship could join the fashion for reasons according to the Simmel or Keynes thinking, it seems that the CAM mechanism of explanation is closer also to axiological action logics, based on the new understanding of life living idea, as the showed in the CAM ideology section. Therefore, the hook to the fashion would be motivated by a symbolic value too, symbolic value roots in the systems of believes that CAM people defend: wellbeing, holistic health, environment relationship.

Briefly, the CAM can boast about being a fashion without subject as the ascription will depend on the product's strength to generate its hook. The mechanism of diffusion, the mimesis, could be motivated for two types of explanation mechanism: by logics of instrumental actions -resolve a decision, but also for symbolic logics. And in this symbolic value, the belief in new ways of understanding health and illness, seems to be the best explanation mechanism. Once the evidence is gotten, that is, once the axiological or instrumental utility is showed, the contagion will be the fashion dissemination mechanism. This mechanism is in the ground of social change toward new medicine forms. 


\section{Conclusions}

These pages have helped to illustrate that CAM preferences are generated for instrumental and axiological reasons. Both reasons are plausible for the understanding of CAM people behavior, though it seems that axiological rationality would be a powerful explanation when we observe the emergence of this trend. On the other hand, a group of innovative people would be who would lead the initiative, and its members could be erudite or businessmen; in any way, they will be the agents of the change. Moreover, they would seem to be the group that accelerate the process until the tipping point, from which the trend expands thanks to the processes of mimesis that already Girard was presenting in other contexts (Girard, 2006, 2012).

It seems to be, in addition, that the trend emerges because it is useful for the society. Beyond the seasonal fashions, the irruption of this disruptive with the mainstream of the medicine-, fashion indicates a process of social change with a new understanding of the health: complete or holistic systems, mental control practices, practices with nature elements, handling body techniques, energetic field inclusion, and new psychologies, all of them are elements that incorporate new dimensions in the health concept, that is, new social and cultural guidances.

The framework of analyses of the theories on fashions and social trends has taken us of the hand to show the emergence, shape adopted, dissemination and consolidation of the CAM. It might be said that we are in the moment of consolidation or not of this trend, key point to know if it will turn into a social practice, or we are present at a transitory phenomenon. The fieldwork carried out would seem to show the second option, though it is true that this type of medicine has entered through the back door in political arena, and faced with strong opposition by certain professional groups (Ramírez, 2015).

What seems certain is that the city of Seville is a place where the emergence and dissemination of a novel health care fashion takes place. The research shows the presence of a diversity of CAM activities and services in this middle range city in the global network cities (Taylor, 2001; Taylor et al., 2009). As a model of middle range city, Seville could represent, therefore, the social expression of a new reality when talking about wellbeing. In Southern Europe, the Andalusian capital region display tendencies on health, an interest for new health manifestations, disruptive innovation to the conventional one.

\section{References:}

Aczel, A. D. (2008) Entrelazamiento: El mayor misterio de la física. Madrid: Crítica.

Angrosino, M. (2012) Etnografía y observación participante en investigación cualitativa. Madrid: Ediciones Morata, S. L. 
Baarts, C., and Pedersen, I. K. (2009) Derivative benefits: Exploring the body through complementary and alternative medicine. Sociology of Health \& Illness, 31(5), 719-733.

Barthes, R. (2005). El sistema de la moda. Madrid: Paidós.

Bartolini, S. (1986). Metodología de la investigación política. In Pasquino, G. (Ed.), Manual de ciencia política. Madrid: Alianza. pp. 39-76.

Bauman, Z. (2009) El arte de la vida. De la vida como obra de arte. Barcelona: Paidós.

Beck, U. (2011) Risk society: Towards a new modernity. London: Sage.

Bericat, E. (1998) La integración de los métodos cuantitativo y cualitativo en la investigación social. Barcelona: Ariel.

Boudon, R. (1981) La lógica de lo social: Introducción al análisis sociológico. Madrid: Rialp.

Bourdieu, P. (1979) La distinction. critique sociale du jugement. Paris: Editions de Minuit.

Cahn, B. R., Delorme, A., and Polich, J. (2010) Occipital gamma activation during vipassana meditation. Cognitive Processing, 11(1), 39-56.

Callejo, J. (1998) Sobre el uso conjunto de prácticas cualitativas y cuantitativas. Revista Internacional De Sociología, (21), 101-126.

Capra, F. (1984) El tao de la física: Una exploración de los paralelos entre la fisica moderna y el misticismo oriental (1st ed.) Madrid: Luis Cárcamo, D.L. 1984.

Dambrun, M., et al. (2012) Measuring happiness: From fluctuating happiness to authentic-durable happiness. Frontiers in Psychology, 3(16), 1-11. doi:10.3389/fpsyg.2012.00016

Davidson, P. (1991). Is probability theory relevant for uncertainty? A post keynesian perspective. The Journal of Economic Perspectives, 5(1), 129-143. Ekman, P., et al. (2005) Buddhist and psychological perspectives on emotions and well-being. Current Directions in Psychological Science, 14(2), 59-63. doi:10.1111/j.0963-7214.2005.00335.x

Elster, J. (2003) Tuercas y tornillos: Una introducción a los conceptos básicos de las ciencias sociales (3a reimp. ed.). Barcelona: Gedisa.

Erner, G. (2013) Sociología de las tendencias. Barcelona: Gustavo Gili.

Foucault, M. (1979) Microfísica del poder (Segunda ed.). Madrid: Las Ediciones de La Piqueta.

George, S. (2013) El Informe Lugano II. Esta vez, vamos a liquidar a la democracia. Barcelona: Deusto.

Girard, R. (2006). Los orígenes de la cultura. conversaciones con Pierpaolo Antonello y Joao Cezar de Castro Rocha. Madrid: Trotta.

(2012). Geometrías del deseo. México: Sexto Piso.

Gladwell, M. (2000) The tipping point: How little things can make a big difference. Boston: Little Brown. 
Goci, E (2013) Complementary and Alternative Medicine (CAM) for pain, herbal anti-inflamatory drugs. European Scientific Journal. 9(9), 90-105.

Goyal, M., et al. (2014) Meditation programs for psychological stress and well-being. A systematic review and meta-analysis. JAMA Internal Medicine, 174(3), 357-368. doi:10.1001/jamainternmed.2013.13018

Hammersley, M. (1989) The dilema of qualitative methods. London: Routledge.

Hammersley, M., and Atkinson, P. (1995) Ethnography : Principles in practice (2nd ed. ed.). London; New York: Routledge.

Hsiao, A., et al. (2006) Variations in provider conceptions of integrative medicine. Social Science \& Medicine, 62(12), 2973-2987. doi:10.1016/j.socscimed.2005.11.056

Keshet, Y., et al. (2013) The use of boundary objects to enhance interprofessional collaboration: Integrating complementary medicine in a hospital setting. Sociology of Health \& Illness, 35(5), 666-681. doi:10.1111/j.1467-9566.2012.01520.x

Kirk, J., \& Miller, M. L. (1986) Reliability and validity in qualitative research. London: Sage.

Lipovetsky, G., and Serroy, J. (2010) La cultura-mundo. respuesta a una sociedad desorientada. Barcelona: Anagrama.

Miles , M. B., and Huberman , A. M. (1994) Qualitative data analysis: An expanded sourcebook (2 ed. ed.). Thousand Oaks, CA: Sage.

Morin, E. (2010) ¿Hacia el abismo? Globalización en el siglo XXI. Barcelona: Paidos Iberica.

OMS. (2013) Estrategia de la OMS sobre medicina tradicional 2014-2023. Hong Kong: OMS.

Ostrom, E. (1999) Institutional rational choice: An assessment of the institutional analysis and development framework. In Sabatier, P. (Ed.), Theories of the policy porcess. Boulder: Westview Press. pp. 35-72.

Observatorio Terapias Naturales (OTN). (2008) Presentación del primer estudio sobre uso y hábitos de consumo de las terapias naturales en España. Madrid: Observatorio Terapias Naturales.

Perez, A., and Holmes, J. (2000) Meditation: Concepts, effects and uses in therapy. International Journal of Psychotherapy, 5(1), 49-58.

Radhika, G., and Kumari, A. (2014) Meditation: A stress reliever. Journal of Evolution of Medical and Dental Sciences, 3(25), 7008-7013. doi:10.14260/jemds/2014/2852.

Ramírez, A. (2015). Las asociaciones de salud y bienestar personal en Andalucía: Oportunidades, motivaciones y anclajes. In Zárate, M.A. (Eds.) Políticas públicas y organizaciones de la sociedad civil. México y España. México D.F.: UNAM.

Ramírez, A. (2015a). Modas y tendencias en medicina complementaria y 
alternativa en Sevilla, ciudad global. In Peer-revision process.

Robertson, T. S. (1967) The process of innovation and the diffusion of innovation. Journal of Marketing, 31, 14-19.

Rogers, E. M., and Shoemaker, F. F. (1971) Communication of innovations. New York: Free Press.

Rubia, F. (2002) La conexión divina. la experiencia mistica y la neurobiología. Barcelona: Crítica.

Ruiz, J. I. (1996) Metodología de la investigación cualitativa. Bilbao: Universidad de Deusto.

Simmel, G. (1957) Fashion. The American Journal of Sociology, 62(6), 541558.

Sointu, E. (2006) The search for wellbeing in alternative and complementary health practices. Sociology of Health \& Illness, 28(3), 330-349. doi:10.1111/j.1467-9566.2006.00495.x

Sproles, G. B. (1974) Fashion theory: A conceptual framework. Advances in Consumer Research, 1, 463-472.

Szekeres, R. A., and Wertheim, E. H. (2015) Evaluation of vipassana meditation course effects on subjective stress, Wellbeing, Self-kindness and mindfulness in a community sample: Post-course and 6-month outcomes. Stress and Health, 31(5), 373-381. doi:10.1002/smi.2562

Taylor, S. J., and Bodgan, R. (1994). Introducción a los métodos cualitativos de investigación. la búsqueda de significados. Barcelona: Paidos.

Taylor, P. J. (2001) Specification of the world city network. Geographical Analysis, 33(2), 181-194.

Taylor, P. J., \& et al. (2009) Measuring the world city network: New results and developments. GaWC Research Bulletin, 300.

Trigg, A. B. (2001) Veblen, bourdieu, and conspicuous consumption. Journal of Economic Issues, 35(1), 99-115.

Vallés, M. S. (2000) Técnicas cualitativas de investigación social. Reflexión metodológica y práctica profesional. Madrid: Síntesis.

\section{Appendix 1. Methodology for the ethnographic fieldwork.}

The ethnographic fieldwork has been conducted with the participant observation procedures pointed out by Ruiz Olabuénaga (1996), Vallés (2000), Miles y Huberman (1994), Angrosino (2012), Hammersley (1989), Hammersley and Atkinsons (1995), Kirk and Miller (1986), and Taylor y Bodgan (1994), among others.

The most important CAM activities carried out are the following:

Title: Ten/Twenty days Vipassana Meditation Course.

Subjet: Introduction to vipassana meditation technique taught by S. N. Goenka.

Venue: Vipassana Meditation Centers (U.S.A, Mexico, Spain, England, Portugal, etc.).

Date: From 2003 to currently.

Title: Yoga courses.

Subject: Learning and practice of Hata, Vinyasa, Asthanga yoga.

Venue: Khajuraho (India) Sevilla (Spain), Mexico D.F. (México). 
Date: From 2005 to currently.

Title: Dr. Hamer, New German Medicine Course.

Subject: Skills in biological health-illness laws.

Venue: Málaga and Cádiz, Spain.

Date: 2009 and 2015.

Title: Hand course - manual etheric medicine.

Subject: Knowledge on energetic healing.

Venue: Holociencia, Madrid, Spain.

Date: 2011.

Title: Psych-K.

Subject: Skills in psychology, kinesiology, biology of transformation.

Venue: Seville, Spain.

Date: 2011.

Among the elements that give validity to the research, it has been worked the credibility (internal validity), with the intention to give coherence and internal consistency to the narrative. This objective has been carried out showing the narratives and the thinking about the process and the object to several CAM professionals, generating then a feedback that improves the internal consistency and the narrative. This way to work, besides, allows to achieve the external validity criteria, because the results of the research come from the information gathered, and not from the researcher bias.

The triangulation (internal validity) has been also carried out with the intention to eliminate bias; the findings has been verified with both interviews and textual analysis, and with the attendance to congresses and conferences. The interviews have been made to $25 \mathrm{CAM}$ informants. The textual analysis has been made to scientific documents and to advertising as well. More than 200 documents of both types have been handle. And below is showed a list with the conferences and congresses:

Title: Meditation course.

Participation: organization.

Venue: Tavira, Portugal

Date: 2012.

Title: The daily life medication.

Event: Seminar.

Participation: organization.

Venue: Universidad Pablo de Olavide, Seville

Date: 2012 and 2013

Ramírez, A (2010) "The education for the health: the individual bio-psico-social dimensions in the classroom" in V Congreso Andaluz de Sociología, Córdoba.

Ramírez, A (2011) "Basic notions for meditation", in V Jornadas Hábitos Saludables, Universidad Pablo de Olavide, Sevilla.

Ramírez, A (2012) "Alternative therapies experiences", in VI Jornadas Hábitos Saludables, Universidad Pablo de Olavide, Sevilla.

Ramírez, A. (2014) "Sociology of trends in health and well-being, comparative SpanishMexican Study", in Foro Académico: propuestas teórico-analíticas para la investigación social en México y España, Universidad Pablo de Olavide, Seville.

Ramírez, A. (2015) "Types of complementary and alternative medicine in a global European city", en 8th European Congress for Integrative Medicine (ECIM), Greater Copenhagen.

Finally, these activities, along with the above, put into evidence a CAM activity of more than a decade. The use, on the one hand, of a range of methods and forms of approach to 
the reality, and on the other hand, during a stable period of time, are the two features associated to the reliability in the social research, both of them applied in this research.

\section{Appendix 2. Methodology for the elaboration of the database}

The information is gathered during the 2013-2014 years. The gathering is made through Internet, locating the information from two basic coordinates: district and activity. The district allows to trace the geographical area selected, to follow the traced areas and to know which have not been still traced. It allows to detect the potential mistakes of the information collected too, because it can be visualized the lack of activities on the geographical area and looking for the causes.

The activity refers to locate the CAM activities existing in the selected geographical area. The search is organized as a fan form: from an existing initial information the range of information has been opened. This first information is related with a) type of the activity, and b) places where is carried out. Along with this form, key words included in Internet search engine has been other way to get activities information.

The variables included in the database are the list below, besides the CAM activities that can be seen by Ramírez (2015a):

1. Type: type of room where the activity is developed --- Values: 1'Asociation' 2'Center' 3'Office room' 4'At home' 5'Herbalist shop' 6'Other'.

2. Name of the association, center, person --- Values: it is a string variable and the complete name is written.

3. Person --- Values: 1'Natural person' 2'Legal entity'.

4. Gender --- Values: 1'Male' 2'Female'.

5. Entity --- Values: 1'Public entity' 2'Private entity'.

6. District --- Values: 1'Macarena' 2 'Norte' 3 'Bellavista-La Palmera' 4 'Distrito Sur' 5 'Triana' 6 'Casco Antiguo' 7 'Nervion' 8 'San Pablo' 9 'Alcosa' 10 'Cerro Amate' 11 'Torreblanca' 12 'Metropolitan area'.

7. Address --- Values: is a string variable that include the postal adress.

8. E-mail ---Values: is a string variable that include the e-mail adress.

9. Phone --- Values: telephone number.

10. Web --- Values: is a string variable that include the Website.

11. Comment --- Values: is a string variable with additional information. 


\section{Appendix 3. Results of factorial analysis}

\section{Communalities}

\begin{tabular}{|l|l|l|}
\hline & Initial & Extraction \\
\hline Integral systems & 1,000 &, 616 \\
Self-awareness Basis & 1,000 &, 581 \\
Nature Elements & 1,000 &, 529 \\
Body Handling & 1,000 &, 612 \\
Energy Basis & 1,000 &, 550 \\
Psychic Basis & 1,000 &, 377 \\
\hline
\end{tabular}

Method of extraction: Principal components analysis.

\section{Total variance explained}

\begin{tabular}{|l|l|l|l|l|l|l|}
\hline \multirow{2}{*}{ Component } & \multicolumn{3}{|l|}{ Initial eigenvalues } & \multicolumn{2}{l|}{ Sums of squared loadings extraction } \\
\hline & & $\begin{array}{l}\text { Variance } \\
\%\end{array}$ & $\begin{array}{l}\text { Cumulated } \\
\%\end{array}$ & Total & $\begin{array}{l}\text { Variance } \\
\%\end{array}$ & $\begin{array}{l}\text { Cumulated } \\
\%\end{array}$ \\
\hline 1 & 1,981 & 33,021 & 33,021 & 1,981 & 33,021 & 33,021 \\
2 & 1,285 & 21,415 & 54,436 & 1,285 & 21,415 & 54,436 \\
3 &, 896 & 14,935 & 69,370 & & & \\
4 &, 692 & 11,535 & 80,906 & & & \\
5 &, 600 & 9,995 & 90,901 & & & \\
6 &, 546 & 9,099 & 100,000 & & & \\
\hline
\end{tabular}

Method of extraction: Principal components analysis.

\section{Matrix components}

\begin{tabular}{|l|l|l|}
\hline & Component & \\
\hline & 1 & 2 \\
\hline Integral systems &, 746 &, 706 \\
Self-awareness Basis & &,- 394 \\
Nature Elements &, 611 & \\
Body Handling &, 782 &, 446 \\
Psychic Basis &, 593 &, 610 \\
\hline
\end{tabular}

Method of extraction: Principal components analysis. 